STUDI MANAGERIA: JURNAL MANAJEMEN PENDIDIKAN ISLAM

Volume 1, Nomor 2, Desember 2019

http://jurnal.radenfatah.ac.id/index.php/studiamanageria

\title{
Manajemen Pembelajaran di Madrasah Aliyah Pondok Pesantren Pancasila Kota Bengkulu
}

\author{
Abdullah \\ Madrasah Aliyah Pondok Pesantren Pancasila, Bengkulu, Indonesia \\ abdullaabdullaabd290@gmail.com
}

\begin{abstract}
This study aims to describe the conditions of the implementation of teaching and learning activities in Madrasah Aliyah Pancasila and reveal the conditions of students both before learning and after learning. Through this research, a complete picture of the teaching implementation process in Madrasah Aliyah Pancasila is obtained, in which the activity and creativity of teachers as teaching staff, infrastructure support and student activity are required. The study used a qualitative approach, using data collection instruments in the form of: questionnaires, interviews and documentation. The aim of this research is to explore important scientific findings from the conditions of teaching and learning activities in the Madrasah Aliyah Pancasila studied, and then look for learning models that pay more attention to the quality / quality of teaching staff, the quality of student input, support of facilities and support of other factors. The results of this study conclude that: (1) The teaching process has not gone well due to the use of less varied teaching methods so that teaching becomes less attractive, (2) A decrease in the quality of output because the teachers have not carried out their teaching assignments professionally, (3) Factors factors which become obstacles / constraints in teaching, namely the quality of input / students that are still low, the sense of responsibility of teachers who are still lacking, communication that has not been running and the lack of infrastructure.
\end{abstract}

Keywords: management, learning

Abstrak. Penelitian ini bertujuan untuk mendeskripsikan kondisi pelaksanaan kegiatan belajar mengajar di Madrasah Aliyah Pancasila serta mengungkap kondisi para siswa baik sebelum belajar maupun sesudah belajar. Melalui penelitian ini, diperoleh gambaran secara lengkap tentang proses pelaksanaan pengajaran di Madrasah Aliyah Pancasila, yang di dalamnya menuntut adanya aktivitas dan kreativitas guru sebagai tenaga pengajar, dukungan sarana-prasarana dan keaktifan para siswa. Penelitian menggunakan pendekatan kualitatif, dengan mengunakan instrumen pengumpul data berupa: angket, wawancara dan dokumentasi. Sasaran peneliti ini adalah menggali temuan ilmiah yang penting dari kondisi kegiatan belajar mengajar di Madrasah Aliyah Pancasila yang diteliti, dan selanjutnya mencari model pembelajaran yang lebih memperhatikan kualitas/mutu tenaga pengajar, kualita input siswa, dukungan sarana-prasarna dan dukungan faktorfaktor lain. Hasil penelitian ini menyimpulkan bahwa: (1) Proses pengajaran belum berjalan secara baik disebabkan oleh penggunaan metode pengajaran yang kurang bervariatif sehingga pengajaran menjadi kurang menarik, (2) Terjadinya penurunan mutu output karena para guru belum menjalankan tugas mengajarnya secara professional, (3) Faktor-faktor yang menjadi penghambat/kendala dalam pengajaran yaitu kualitas input/siswa yang masih rendah, rasa tanggung jawab pengajar yang masih kurang, komunikasi yang belum berjalan dan kurangnya sarana-prasarana.

Kata kunci: manajemen, pembelajaran 


\section{PENDAHULUAN}

Perjalanan bangsa Indonesia guna mencapai masyarakat yang ideal terus diupayakan di berbagai sektor kehidupan manusia, khususnya lembaga pendidikan Islam. Lembaga pendidikan Islam sebagai wadah atau tempat berlangsungnya proses pendidikan Islam yang secara bersamaan berlangsung di dalamnya proses pembudayaan (Soewarso, 1996:144). Lembaga-lembaga pendidikan Islam di Indonesia terdapat banyak jenis dan bentuknya, diantaranya; pesantren, madrasah, majelis taklim, dan Institut Agama Islam Negeri (Hasbullah, 1996:39).

Dalam konteks pendidikan pesantren di Indonesia juga ternyata tidak seragam, masing-masing pondok pesantren memiliki ciri khas atau keunikan sendiri, sehingga sulit dibuat satu perumusan yang dapat mencakup semua pesantren.

Namun kita tahu bahwa pondok pesantren merupakan lembaga tertua, dan telah berfungsi sebagai salah satu benteng pertahanan ummat Islam, pusat dakwah dan pusat pengembangan masyarakat muslim di negara Republik Indonesia. Sebab, pesantren merupakan lembaga pendidikan tradisional-modern (salaf-khalaf) (Wahjoetomo, 1997:83-84). Secara umum tujuan pendidikan di lembaga pesantren yakni untuk memahami, menghayati, dan mengamalkan ajaran Islam dengan mengkhususkan pada pentingnya moral/akhlak sebagai pandangan dan pedoman hidup manusia. Seiring juga dengan perkembangan dan tuntutan zaman kurikulum yang dikembangkan di banyak pesantren juga meliputi kurikulum life skill dalam rangka membekali para santri bidang-bidang keterampilan tertentu sesuai dengan minat dan bakat mereka.

Penyelenggaraan pendidikan pesantren akrab disebut pendidikan asrama yang merupakan komunitas tersendiri di bawah asuhan seorang kyai dan dibantu oleh beberapa orang pengasuh yang hidup secara bersama-sama dengan santri dalam melakukan aktivitas-aktivitas, baik dalam kegiatan peribadatan maupun dalam proses belajar-mengajar selama 24 jam. Dengan maksud untuk menata kehidupan secara kolektif yang merupakan satu kesatuan dan mampu bernaung sebagai komunitas pesantren dengan kata lain hidup secara bersama-sama (Ziemek, 1986:130-131).

Provinsi Bengkulu dalam usia 53 tahun ini dikenal dengan kota jasa. Sebagai ibu kota provinsi, Kota Bengkulu dalam kemajuannya bergerak pada beberapa sektor: transportasi, perdagangan, dan jasa. Ketiga sektor inilah yang menjadi program pemerintah daerah dalam mendapatkan pendapatan anggaran kota. Di samping itu juga, Kota Bengkulu telah memiliki Pondok 
$\overline{\text { Pesantren Pancasila yang ternama di Sumatera Bagian Selatan (Palembang, }}$ Jambi, Lampung) dan telah berusia 40 tahun.

Pesantren Pancasila yang mula-mulanya dari Mushalah, hingga saat ini telah mampu menyelenggarakan 4 lembaga pendidikan formal Madrasah Aliyah Pancasila (MA Pancasila), Sekolah Menengah Umum Pancasila (SMU Pancasila), Madrasah Tsanawiyah Pancasila (MTs Pancasila), dan Sekolah Lanjutan Tingkat Pertama Pancasila (SLTP Pancasila). Akan tetapi sebagai lembaga pendidikan Islam yang akrab dengan kehidupan masyarakat, sudah barang tentu memiliki beberapa catatan-catatan atau pekerjaan yang belum terselesaikan dalam pengelolaan pesantren secara baik, khususnya peran guru "ustadz" dalam poses pengajaran di Madrasah Aliyah Pancasila. Jadi bahwa betapa pentingnya proses pengajaran yang dilakukan secara baik di Madrasah Aliyah, justru itu guru merupakan faktor utama, artinya guru sebagai tenaga pengajar yang berprofesi sebagai tenaga pendidik dalam pencapaian keberhasilan suatu lembaga pendidikan.

Menurut Jammes, "Tugas dan peran guru antara lain: menguasai dan mengembangkan materi pelajaran, merencanakan dan mempersipkan pelajaran sehari-hari, mengontrol dan mengevaluasi kegiatan siswa (Jammes dalam Sardiman A. M. 1990:142). Sedangkan menurut Rifa'i, bahwa "di dalam situasi pengajaran, gurulah yang memimpin dan bertanggung jawab penuh atas kepemimpinan yang dilakukan itu. Ia tidak melakukan instruksiinstruksi dan tidak berdiri di bawah instruksi manusia lain kecuali dirinya sndiri, setelah masuk dalam situasi kelas (Rifa'i, 2003:135).

Berdasarkan survey yang dilakukan oleh penulis bahwa proses pengajaran yang dilakukan oleh guru mulai dari perencanaan, pelaksanaan kegiatan sampai evaluasi program tidak lanjut belum berjalan sebagaimana mestinya sedangkan yang kita pahami bahwa kemampuan mengelola dalam proses belajar mengajar adalah suatu kesanggupan atau kecakapan para guru dalam menciptakan suasana komunikasi yang edukatif antara guru dengan peserta didik, guru dengan guru dan guru dengan masyarakat sekitarnya. Dengan harapan segi kohnitik, efektif dan psikomotor tercapai yang merupakan upaya mempelajari sesuatu berdasarkan perncanaan sampai dengan tahap evaluasi dan tidak lanjut agar proses pengajaran tercapai.

Terkait dengan latar belakang di atas bahwa proses pengajaran yang dilaksanakan oleh guru-guru di Madrasah Aliyah Pancasila (MA Pancasila) menjadi sasaran penelitian dalam penelitian ini dengan mengacu kepada tiga proses terpenting dalam proses belajar mengajar yang meliputi: menyusun program pengajaran, menyajikan atau melaksanakan pengajaran dan melaksanakan evaluasi belajar. Oleh karena itu, penelitian ini berjudul 
Manajemen Pembelajaran Madrasah Aliyah Pondok Pesantren Pancasila Kota Bengkulu.

\section{KAJIAN LITERATUR}

Kata "pengelolaan" menurut Kamus Umum Bahasa Indonesia adalah: "Cermat dan sesuai dengan tujuan" (Poerwadarminta 1999:26). Sementara itu Baego Ishak dalam bukunya, Pengembangan Kurikulum: Teori dan Tehnik", menyebutkan bahwa: "Pengelolaan adalah suatu kegiatan atau kerja yang dilakukan secara sistematis, bertahap, cermat dan selalu berorientasi pada pencapaian tujuan secara maksimal sesuai dengan perencanaan" (Ishak, 1998:21). Disamping itu, kata kelas menurut Oemar Hamalik adalah "suatu kelompok orang yang melakukan kegiatan belajar bersama yang mendapatkan pengajaran dari guru" (Hamalik, 1991:198). Hal senada juga dikemukakan oleh Suharsimin Arikunto, mengemukakan pengertian kelas adalah "sekelompok siswa yang pada waktu yang sama menerima pelajaran yang sama dari guru yang berlangsung di dalam ruangan" (Arikunto, 1988:200).

Pengelolaan kelas dimaksudkan untuk menciptakan lingkungan belajar yang kondusif bagi siswa sehingga tercapai tujuan pembelajaran secara efektif dan efisien. Ketika kelas terganggu guru berusaha mengembalikannya agar tidak terjadi penghalang bagi proses belajar mengajar. Dengan demikian, dapat disimpulkan bahwa pengelolaan kelas adalah upaya mengoptimalkan kelas sehingga menjadi lebih produktif, baik di dalam mengikuti proses belajar mengajar maupun di dalam interaksi guru dan siswa, siswa dengan siswa sehingga perbedaan kemampuan siswa di dalam kelas dapat teratasi dengan baik oleh guru.

Pengelolaan kelas bukanlah suatu hal yang mudah dan ringan, akan tetapi guru tidak pernah merasa jenuh dan kemudian jera di dalam mengelola kelas setiap kali mengajar. Gagalnya, seorang guru dalam mencapai tujuan pengajaran disebabkan ketidakmampuan guru dalam mengelola kelas. Indikator dari kegagalan itu adalah prestasi belajar siswa rendah, tidak sesuai dengan standar atau batasan ukuran yang telah ditentukan. Karena itu, dalam pengelolaan kelas merupakan salah satu kompetensi yang harus dimiliki oleh guru dalam kerangka mencapai keberhasilan proses belajar mengajar.

Adapun tindakan yang dapat dilakukan guru di dalam pengelolaan kelas agar proses belajar mengajar berlangsung efektif. Tindakan tersebut dapat berupa tindakan pencegahan yaitu dengan menyediakan kondisi fisik maupun kondisi sosio emosional sehingga terasa benar oleh peserta didik, 
$\overline{\text { rasa kenyamanan dan keamanan untuk belajar. Tindakan lain dapat berupa }}$ tindakan korektif terhadap tingkah laku peserta didik yang menyimpang dan merusak bagi proses belajar mengajar yang sedang berlangsung.

Berdasarkan uraian di atas dapat disimpulkan bahwa cara pengelolaan kelas di dalam proses belajar mengajar sangat penting dilakukan oleh guru karena dapat menciptakan suasana kelas yang hidup, kreatif dan saling bekerjasama antara anggota kelas lainnya. Oleh sebab itu, seorang guru harus memahami terlebih dahulu masalah yang muncul di dalam kelas sehingga persoalan sekecil pun dapat di selesaikan dan tidak menganggu proses belajar mengajar, seperti siswa yang pandai hendaknya didekatkan dengan siswa bodoh dan siswa yang nakal hendaknya diletakkan dibangku barisan depan.

Di samping itu guru harus memperhatikan seluruh siswa pada saat proses belajar mengajar dan jangan membiasakan membelakangi siswa. Hal lain yang perlu diperhatikan adalah guru harus dapat memberikan contoh yang baik kepada siswa seperti membiasakan mengucapkan salam dan memberikan motivasi kepada siswa yang kurang di dalam mengikuti proses belajar mengajar.

\section{METODE PENELITIAN}

Penelitian ini menggunakan metode deskriptif analitik dengan pendekatan kualitatif. Penggunaan metode dan pendekatan ini bertujuan mendeskripsikan dan menganalisa data tentang peranan guru dalam pengelolaan Madrasah Aliyah Pancasila. Teknik sampling dalam penelitian kualitatif jelas berbeda dengan non kualitatif. Pada penelitian non kualitatif sampel itu dipilih dari suatu populasi sehingga dapat digunakan untuk mengadakan generalisasi, jadi sampel benar-benar mewakili ciri-ciri suatu populasi. Pada penelitian paradigma alamiah peneliti mulai dari asumsi bahwa konteks itu kritis, sehingga masing-masing konteks itu ditangani dari segi konteksnya sendiri (Moeleong 1990:165).

Teknik pengumpulan data dilaksanakan oleh peneliti sendiri. Peneliti langsung terjun ke lapangan untuk mengumpulkan sejumlah informasi yang dibutuhkan berkenaan dengan upaya meneliti tentang peran guru dalam pengelolaan Madrasah Aliyah Pancasila mengenai penguatan output yang ada. Cara ini ditempuh agar dapat memahami kenyataan yang terjadi di lapangan sesuai dengan konteksnya. S. Nasution (1992:9-10) mengemukakan: "Salah satu ciri penelitian naturalistik adalah mengutamakan data langsung atau first hand." Untuk itu peneliti terjun sendiri ke lapangan dalam mengadakan penelitian. 
Teknik yang digunakan dalam pengumpulan data penelitian ini adalah pengamatan (observasi), wawancara dan studi dokumentasi. Ketiga teknik tersebut dipilih dengan harapan dapat saling melengkapi untuk memperoleh data yang diperlukan. Sedangkan data yang diperoleh diklasifikasikan menjadi data primer dan data skunder.

\section{HASIL DAN PEMBAHASAN}

Pelaksanaan pengajaran yang dilaksanakan oleh guru-guru Madrasah Aliyah Pancasila dapat dilihat dari hasil wawancara yang dilakukan oleh peneliti bahwa faktor dari pengajar yang tidak menggunakan metode dan model pembelajaran tertentu. Adapun faktor dari guru yang mengajar, seperti a). Faktor kurang tepatnya metode yang digunakan, hal ini terjadi karena guru mengajar hanya melepaskan tugas saja dan kurangnya demonstrasi yang diadakan, sehingga siswa kurang merespon. b). Faktor guru tidak melakukan aksi atau menggunakan model dalam penyampaian pelajaran. c). Faktor lingkungan dalam belajar, seperti pengaruh teman saat belajar. d). Faktor ekonomi dan pekerjaan orang tua yang kurang mendukung, karena penghasilan orang tua siswa sangat tidak mencukupi untuk memenuhi kebutuhan belajar siswa, sebab setiap bulannya keterlambatan pembayaran terus terjadi. e). Tidak disiplinnya pengawas asrama saat siswa/i di asrama dan guru saat pergantian jam belajar mengajar. f). Faktor kurangnya sarana dan prasarana anak untuk belajar bagi siswa/i (Yakin Sobri, Carateker Kepsek, Wawancara, Selasa, 14 Oktober 2013).

Dalam menyampaikan pelajaran, faktor lainnya yaitu guru tidak mampu memberikan motivasi kepada para siswa. Faktor guru yang mengajar, seperti a). Faktor tidak menjadikan satuan pelajaran dan program yang ada sebagian pedoman sehingga dalam penyampaian materi guru tidak memiliki tujuan yang tepat sesuai dengan rencana, karena kebanyakan guru yang sibuk dengan urusan rumah tangganya masing-masing dan program yang dibuatkan dan disiapkan hanya untuk administrasi kenaikan pangkat saja. b). Faktor dari siswanya itu sendiri seperti pengaruh dari teman yang malas belajar sehingga banyak siswa yang lain terpengaruh, dan kurang semangatnya siswa dalam belajar karena pengaruh guru dalam sistem cara penyampaian materi yang diberikan, seperti hanya menyampaikan materi dengan metode ceramah saja. c). Faktor ekonomi orang tua siswa/i yang mayoritas rendah. d). Di asrama siswa/i tidak ketatnya pengawasan, pengontrolan dan membimbing dalam belajar di asrama. e). Siswa/i di asrama waktunya setelah pulang sekolah dihabiskan waktu dengan hurahura, (Tarmizi, TU dan Guru Penjas, Wawancara, Selasa, 14 Oktober 2013). 
Disaat menyampaikan materi, sehingga para siswa/i tidak ada perubahannya. Di samping itu faktor pendukung juga adalah faktor laukpauk yang dikonsumsi siswa/i. Dengan perkataan lain bahwa faktor gizi yang dikonsumsikan oleh para siswa/i di asrama. Selanjutnya tidak hanya penguasaan dan pemahaman terhadap materi dan kurikulum yang diutamakan dalam pelaksanaan pengajaran yang dilaksanakan. Namun ada juga faktor sarana prasarana, perhatian atau control guru, komunikasi dengan orang tua, dukungan orang tua, serta lingkungan yang kondusif. Adapun hasil wawancara dengan guru sebagai berikut: a). Faktor kurangnya sarana dan prasarana di sekolah seperti kurangnya buku paket dan alat peraga. b). Faktor lingkungan asrama, kurangnya perhatian dan pengontrolan para pengasuh asrama, kurangnya pengontrolan orang tua terhadap hasil yang dicapai oleh anak. c). Sulitnya membangun komunikasi dengan orang tua siswa/i. d). Faktor ekonomi orang tua yang rendah, hal ini terbukti dari tersendatnya orang tua dalam membayar keuangan sekolah, jika ditagih pada siswa, siswa menjawab orang tuanya belum ada uang. Melihat dari sini sangat wajar sarana dan prasarana siswa tidak terpenuhi. e). Proses penyampaian kurikulum yang belum berjalan secara maksimal. f). Faktor motivasi siswa/i itu sendiri, baik dilaihat dari segi kesiapannya untuk menerima pelajaran atau kekurangan gizi yang dikosumsikan selama di asrama (Nuriyah, Guru Ushul Fiqhiyah, Wawancara, Rabu, 15 Oktober 2013).

Pendapat yang lain dikemukakan para siswa kelas XI mengatakan bahwa dalam proses belajar di Madarash Aliyah Pancasila menunjukkan bahwa siswa cenderung kurang perhatian terhadap pelajaran yang disampaikan. Ini semua akibat tidak lengkapnya sarana dan prasarana yang dimiliki, sebagaimana pernyataan mereka bahwa ada beberapa factor yang mempengaruhi mereka, yakni: a). Faktor lain juga kurangnya sarana dan prasarana sekolah seperti buku pelajaran karena saya tidak pernah dipinjami buku pelajaran, untuk membeli buku orang tua saya tidak mampu. b). Metode yang dipergunakan oleh guru adalah metode catat buku sampai habis. c). Guru yang tidak konsisten dengan waktu yang telah disediakan. d). Sanksi tidak begitu diterapkan oleh para pengelola. e). Di ruanganpun materi yang disampaikan oleh guru tidak ada perubahan yang mendasar dari hari kehari, (Wawancara, Selasa, 28 Oktober 2013). Di samping itu juga guru yang tidak menggunakan waktu secara baik, pernyataan mereka: a). Guru yang tidak tepat waktu yang telah diatur oleh pihak pengelola. b). Sanksi tidak diterapkan. c). Tidak lengkapnya sarana dan prasarana disaat guru menjelaskan pelajaran yang membutuhkan alat peraga. d). Guru tidak menggunakan metode atau gaya dalam menyampaikan pelajaran, art1inya 
guru hanya di tempat duduk. e). Siswa yang tidak memiliki pedoman pelajaran "buku cetak" lebih banyak dari jumlah yang memiliki, (Lisma Sukaisi, Siswa Kelas X, Wawancara, Sabtu, 01 Nopember 2013). faktor lain juga disaat mengajar guru dalam menjelaskan materi tidak memperagakan di depan kelas secara baik, menurut hasil wawancara: Sarana dan prasarana yang tidak lengkap dalam memperagakan didepan kelas. Di samping guru tidak menggunakan metode "gaya" yang bervariasi dalam penyampaian pelajaran. Kurangnya buku panduan bagi siswa/i "referensi", (Alvian, Siswa Kelas X, Wawancara, Sabtu, 01 Nopember 2013). Selanjutnya sanksi yang tidak ketat atau tegas "kurang disiplin" a). Guru yang belum mampu menggunakan waktu yang telah disediakan semaksimal mungkin khususnya selalu terlambat saat masuk kelas. b). Sanksi yang tidak ketat untuk dilaksanakan. d). Sarana yang sangat kurang khususnya untuk alat peraga, (Elvia Susanti, Siswa Kelas X, Wawancara, Sabtu, 01 Nopember 2013). Guru dalam penyampaian materi guru tidak menggunakan metode yang bervariasi. Menurut siswa: a). Sanksi yang tidak tegas. b). Sarana dan prasrana yang tidak lengkap "alat peraga". c). Metode "gaya" yang tidak berubah-rubah dari hari-kehari "guru hanya duduk saja", (Depy Emilda Sari, Siswa Kelas X, Wawancara, Sabtu, 01 Nopember 2013).

Pendapat lain menyatakan bahwa proses belajar mengajar di Madrasah Aliyah Pancasila menerapkan metode yang tidak menarik bagi siswa dalam mengikuti belajar yang diajarkan di sekolah. Sebagaimana pernyataan wali siswa: a). Metode yang digunakan oleh guru disaat menyampaikan materi tidak mendapat simpati atau menarik dari siswa/i. b). Sanksi yang tidak jelas baik dari sekolah/lembaga maupun asrama. c). Tidak tersedianya sarana parasarana seperti: buku pelajaran sehingga untuk belajar di asrama tidak mempunyai pedoman, tidak tersedianya buku pelajaran ini dikarenakan sulitnya keuangan untuk membelinya (khususnya anak saya) dan begitu juga kemungkinan permasalahan yang di hadapi wali murid lain karena yang saya tahu jenis pekerjaan orang tua siswa/i rata-rata sebagai petani biasa yang memiliki penghasilan yang pas-pasan, (Baharudin, Wali Siswa, Wanwancara, Senin, 10 Nopember 2013). Pendapat di atas juga didukung oleh pendapat Surnawati (Wawancara Sabtu, 15 Nopember 2013) yang menyebutkan bahwa "menurut pengamatan saya di samping metode, keadaan ekomnomi wali murid (khususnya yang berada di sekitar saya) tergolong rendah hal ini jelas sangat jelas sangat berpengaruh terhadap pendidikan anak".

Sedangkan faktor yang lain dalam pembelajaran di Madarash Aliyah Pancasila adalah kekurangan perhatian dari pengawas asrama sebab orang tua menganggap anaknya telah diserahkan ke asrama ataupun kesekolah 
$\overline{\text { untuk membimbing, mengontrol belajarnya, sebagaimana menurut M. Yaman }}$ bahwa: a). Kekurangan perhatian dari pengawas asrama, orang tua menganggap anak di serahkan kesekolah untuk membimbing, mengontrol belajar anak sehari-hari. b). Faktor dari guru, dalam meyampaikan materi pelajaran sepertinya guru kurang persiapan dan kurang menguasai bahan, hal ini pernah terjadi pada anak saya guru salah menjelaskan materi pada siswa. c). Sarana dan prasarana sekolah kurang, karena anak saya khususnya tidak mendapat buku pinjaman pelajaran dari sekolah, (M. Yaman, Wali Siswa, Wawancara, Selasa, 18 Nopember 2013). Di samping itu kurangnya sarana dan prasarana yang dimilki oleh Madrasah Aliyah Pancasila. Sebagaimana pendapat wali siswa: a). Kurangnya sarana prasarana sekolah hal ini dapat di lihat tidak adanya buku/kurangnya buku pinjaman untuk siswa. b). Kurangnya kegiatan praktikum/demonstrasi dalam pelajaran yang mestinya dilaksanakan dengan praktek. c). Kurangnya komunikasi antara wali murid dengan pihak sekolah. d). Orang tua memberikan sepenuhnya kepada pihak lembaga untuk membina para anak-anaknya, (Jaharudin, Wali siswa, Wawancara, Selasa, 18 Nopember 2013). Selanjutnya faktor lainnya komunikasi lembaga yang terputus sehingga lembaga memiliki tanggungan yang amat berat dalam membentuk kualitas sumber daya manusia untuk bersaing dengan lulusan yang lainnya. Sebagaimana pendapat wali siswa: "Sarana dan prasarana yang minim dan komunikasi antar wali dengan sekolah sangat kurang. Kegiatan praktikum yang kurang terlaksana di sekolah. Sebuah pandangan bahwa wali menyerahkan sepenuhnya putraputri untuk diajarkan dan dididik oleh lembaga dalam hal ini pondok pesantren Pancasila Bengkulu". (Ahmad Sohar, Wali Siswa, Wawancara, Sabtu, 22 Nopember 2013).

Madrasah Aliyah Pancasila berdiri di bawah naungan Yayasan Pancasila yang mempunyai tujuan yang sudah diprogram dari awal yaitu memajukan pendidikan, menghindarkan dari buta huruf atau kebodohan. Tenaga pendidik atau guru yang mengajar di Madrasah Aliyah Pancasila ini berjumlah 21 orang, yang terdiri dari tenaga pendidik yang diangkat pemerintah dan yang diangkat oleh sekolah sendiri yang diperbantukan.

Hasil wawancara menjelaskan bahwa proses pengajaran di Madrasah Aliyah Pancasila guru tidak membuat perencanaan mengajar yang jelas seperti Rencana Pengajaran, sebagaimana menurut pendapat Abdullah: a). Faktor guru yang mengajar tidak menjadikan satuan pelajaran dan program yang ada sebagai pedoman sehingga dalam penyampaian materi guru tidak memiliki tujuan yang tepat sesuai dengan rencana, karena kebanyakan guru yang sibuk dengan urusan rumah tangganya masing-masing dan program 
yang dibuatkan dan disiapkan hanya untuk administrasi kenaikan pangkat saja. b). Guru yang di saat belajar mengajar kebanyakan tidak mengunakan analis materi pelajaran "AMP" dan tujuan pembelajaran khusus "TPK". c). Faktor dari siswanya itu sendiri seperti pengaruh dari teman yang malas belajar sehingga banyak siswa yang lain terpengaruh, dan kurang semangatnya siswa dalam belajar karena pengaruh guru dalam sistem cara penyampaian materi yang diberikan, seperti hanya menyampaikan materi dengan metode ceramah saja. g). Guru yang tidak bisa melakukan pendekatan kepada siswa/i dalam hal memberi motivasi atau rangsangan terhadap siswa/i. e). Guru tidak memanfaatkan waktu yang ada semaksimal mungkin; guru selalu cerita dan berdongeng. f). Faktor ekonomi orang tua siswa yang mayoritas rendah, dan kurangnya perhatian orang tua hal ini terjadi karena orang tua siswa jarang datang ke asrama, karena sibuk mencari nafkah dalam melengkapi kebutuhan sehari-hari. Sehingga anakanaknya cukup dikontrol dan dibimbing selama mengikuti pendidikan ini oleh pengasuh asrama. Di samping siswa/i setelah pulang ke asrama dihabiskan untuk bermain-main. g). Peran ganda guru yang memegang beberapa studi pelajaran, sebab masih adanya jam yang kosong dan itu bukan materi yang pokok seperti; penjas. h). Sarana dan prasarana yang tidak terpenuhi oleh lembaga, (Abdullah, Guru PPKn, Wawancara, Rabu, 15 Oktober 2013). Para siswa/i yang sangat terpengaruh oleh teman-teman ditambah dengan semangat untuk belajar yang kurang, dan guru yang tidak mampu melakukan pendekatan terhadap para siswa dalam belajar "bimbingan" dan sangat terkesan guru memiliki peran dalam mengajar. Artinya, "penjelasan berbeda dengan materi yang disampaikan".

Proses pengajaran yang dilakukan di Madrasah Aliyah sangat terkesan bahwa guru hanya mengajar sekedarnya saja di samping perencanaan yang tidak jelas dan guru masih ada yang berperan ganda, sebagaimana hasil wawancara sebagai berikut: "Beberapa faktor tersebut antara lain: a). Faktor dari guru yang mengajar hanya sekedar melepaskan tugas saja, karena tidak mempunyai waktu untuk menyiapkan rencana pengajaran karena mengurus keluarga dan juga banyaknya mata pelajaran yang dipegang sehingga hal-hal pengajaran tidak sempat untuk direncanakan. b). Faktor dari siswa sendiri yaitu malas dan tidak bersemangat hal ini disebabkan dalam hal gizi kurangnya kualitas gizi yang dikonsumsi anak, karena untuk memenuhi kebutuhan gizi dibutuhkan biaya. c). Sedangkan tingkat penghasilan orang tua siswa yang pas-pasan saja, hal ini dapat dilihat dari jenis pekerjaan orang tua siswa itu sendiri yang mayoritas petani yang hasil panenpun tidak dapat dipastikan. d). Disiplin guru yang kurang; ketepatan waktu, metode mengajar 
$\overline{\text { dan penyampaian alat peraga. e). Peran ganda dalam penyampaian pelajaran }}$ yang saya lakukan sesuai dengan permintaan saya dan pihak manajemen menerima usulan tersebut. f). Faktor lingkungan di asrama siswa, seperti kurangnya perhatian atau pengawasan dari pengasuh asrama dan orang tua sudah menyerahkan sepenuhnya kepada lembaga terhadap kemajuan dan perkembangan belajar siswa/i dalam mengikuti dalam melaksanakan proses pengajaran". (Isma Juita, Guru Bahasa Arab, Wawancara, Rabu, 15 Oktober 2013). Dengan perkataan lain bahwa guru di Madrasah Aliyah Pancasila hanya melakukan tanggung jawab bukan melakukan keprofesionalannya seorang yang memiliki keahliannya. Namun di sisi lain bahwa penyelenggaraan pendidikan yang dimaksud pengajaran adalah orang yang memiliki kesiapan dalam penyampaian materi dan mampu memberi perencanaan, pengorganisasian, dan pengelolaan secara baik. Dengan kata lain seorang pengajar yang mampu memberi bimbingan terhadap perkembangan siswa dalam peningkatan kemampuan yang dimilikinya. Sebagaimana hasil wawancara: a). Faktor dari guru yang mengajar tidak menyiapkan rencana pengajaran. b). Faktor dari siswanya kurang bergaira dan terkesan malas. c). Guru yang tidak siplin dan metode mengajar yang terbatas. d). Guru berperan ganda dalam mengajar. e). Faktor lingkungan di asrama kurangnya perhatian atau pengawasan dari pengasuh asrama, (Emilyadi , Guru Khot dan Penjas, Wawancara, 14 Oktober 2013).

Pendapat lain yang peneliti temui bahwa proses pengajaran di Madrasah Aliyah Pancasila guru yang terlalu kaku dalam memberikan materi pelajaran, perencanaan belajar yang tidak jelas, faktor lain guru tidak memberi kesempatan kepada siswa/i untuk bertanya terhadap materi yang telah disampaikan. Di samping itu guru tidak bisa mengendalikan kenakalan siswa, sehingga siswa yang lain terpengaruh, dan kurang semangatnya siswa dalam belajar karena pengaruh guru dalam sistem cara penyampaian materi yang diberikan, ini semua sangat terkait sekali dengan caranya menyampaikan materi dan metode yang ada. Sebagaimana pendapat Musriati (Guru Hadits) yang menyatakan ada beberapa factor yang menghambat guru, yaitu: a). Faktor guru yang mengajar menggunakan waktu yang disediakan semaksimal mungkin. b). Guru tidak menjadikan satuan pelajaran dan program yang ada sebagai pedoman sehingga dalam penyampaian materi guru tidak memiliki tujuan yang tepat sesuai dengan rencana. c). Guru kebanyakan yang sibuk dengan urusan rumah tangganya masing-masing dan program yang dibuatkan dan disiapkan hanya untuk administrasi kenaikan pangkat saja. d). Guru tidak memberikesempatan kepada sisa/i untuk bertanya terhadap materi yang telah disampaikan. e). 
Guru tidak bisa mengendalikan kenakalan siswa, sehingga siswa yang lain terpengaruh, dan kurang semangatnya siswa dalam belajar karena pengaruh guru dalam sistem cara penyampaian materi yang diberikan, seperti hanya menyampaikan materi dengan metode ceramah saja. f). Guru tidak memanfaatkan waktu yang ada semaksimal mungkin; guru selalu berdongeng. g). Guru tidak mampu mengelola kelas dengan baik, (Musriyati, Guru Hadits, Wawancara, Minggu, 23 Nopember 2013).

Guru pada kondisi sekarang ini menuntut kewajibannya, tidak sematamata melulu mengajar dalam arti kata bahwa guru menyampaikan keterangan-ketrangan dan fakta-fakta dari referensi "buku" kepada siswa/i, memberi tugas dan memeriksanya, tetapi juga guru diharapkan memperhatikan kepentingan-kepentingan lembaga yang kadang-kadang sangat kompleks dalam mencapai profesionalismenya.

Profesionalisme merupakan syarat utama keberhasilan seseorang dalam menjalankan tugas dan mengemban tanggung jawab. Seseorang dapat melaksanakan tugas secara profesional jika memiliki kompetensi tertentu sesuai bidang tugas yang dijalani. Terwujudnya kompetensi disebabkan oleh perpaduan kemampuan intelektual, pengetahuan dan skill yang terintegrasi dalam pribadi seseorang. Dengan kata lain bahwa kompetensi dapat juga dikatakan kemampuan teknis adalah kemampuan melaksanakan sesuatu yang diperoleh melalui pendidikan dan pelatihan sebagai perbuatan rasional, dan memenuhi konsentrasi keilmuan tertentu dalam pelaksanaan tugasnya dan tercapainya harapan pelangan. Sesuai dengan Soemarsoe (1996, hlm. 7) yang mengutip pendapat Demings meletakkan kerangka pemikiran dalam perbaikan mutu secara berkelanjutan yang terdiri dari hal-hal berikut."(1) Reaksi berantai untuk perbaikan kualitas. (2) Transformasi organisasi. (3) Peran esensial pimpinan. (4) Hindari praktik-praktik manajemen yang merugikan. (5) Penerapan system profoun knowledge".

Intinya pernyataan ini adalah perbaikan output atau produk akan meningkat kepuasan pelangan costamers dalam pendidikan. Ini semua tidak terlepas dari pada perbaikan secara bekelanjutan dan proses kerja dan perbaikan kinerja organisasi yang didukung secara aktif serta terbagunnya interaksi atau komunikasi diberbagai komponen yang akan terlibat. Bila kita kembalikan pada guru yang merupakan profesi juga memiliki krateristik tersendiri. Maka oleh sebab itu dalam pelaksanaan tugasnya membutuhkan kemampuan teknis yang diperoleh melalui pendidikan ataupun pelatihan, berupa perbuatan yang rasioanal dan memiliki konsentari atau spesifikasi tertentu dalam pelaksanaan tugasnya. Untuk menjadi guru yang baik maka dituntut adanya sejumlah kompetensi yang harus dimilikinya. 
Manajamen mutu terpadu menawarkan, setidaknya ada empat hal yang perlu dikemukakan lebih mendalam dalam menyelesaikan persoalan mutu pendidikan. Hal-hal tersebut adalah sebagai berkut.

1. Kepuasan Customer

Suatu hal yang menakjubkan dari perubahan paradigma adalah fokus atas pencapaian dan pemuasan harapan pelanggan atau customers. Dalam perkataan lain bahwa pemuasan harapan pelanggan ini berarti mengantisipasi kebutuhan pelanggan masa datang. Mengambil resiko dan mengembangkan produk atau output, serta melayani pelanggan yang tidak pernah mereka lihat, namun mereka suka atau membutuhkan.

Dalam halnya penyelenggaraan pendidikan sekolah yang terdiri dari penyedia (suppliers), pelanggan (customers), dan produk (lulusan). Seorang pelanggan, (masyarakat dan unsur-unsurnya). Menurut Syafarudin yang mengutif pendapat Sallis (2002, hlm. 37) bahwa "pendidikan yang termasuk pelanggan dalam (internal customer) adalah pegawai, pelajar dan orang tua pelajar. Sementara pelanggan luar (external customer) mencakup akademi dan universitas, bisnis, militer, dan masyarakat luas". Demikian pula lembaga pendidikan sekolah menengah pertama, sekolah menengah atas dan perguruan tinggi. Hal ini penting dikenali oleh pimpinan lembaga pendidikan atau kepala sekolah dan sumber daya personelnya untuk bekerja sama antara supervisor (penyedia) dan pelanggan agar menghasilkan produk atau output yang dapat mencapai kepuasan para pelanggan pendidikan. Dengan perkataan lain bahwa para pendidik harus bertanggung jawab terhadap urusan mereka secara proaktif. Artinya, mereka harus, membangun penyelesaian masalah yang masuk akal (reasonable) dengan mengindentifikasi dan menunjukan penyelesaian akan persoalan yang dihadapi.

2. Perbaikan Terus Menerus

Perbaikan terus menerus berarti sesuatu yang belum pernah dilakukan. Melalui suatu tindakan pengajaran atas mutu, prosesnya harus secara terus menerus diperbaiki dengan diubah, ditambah, dikembangkan, dan dimurnikan. Artinya, bisnis yang dikembangkan seseorang atau institusi akan menjadi harapan dan terpercaya bila mereka dapat memuaskan pelanggan hari ini dan seterusnya dapat memuaskan dalam harapan mereka dengan mengintegrasikan Total Quality atau mutu terpadu ke dalam sekolah, terutama bila disadari bahwa sistem yang ada sekarang belum bekerja dengan baik.

Oleh karena itu, tuntutan terhadap pelayan terhadap pelayanan terbaik juga menjadi perhatian manajemen mutu terpadu, tak terkecuali dalam pendidikan. Sekolah-sekolah pada dewasa ini tidak hanya cukup menawarkan program studi dengan kurikulum tertentu, 
lalu orang tua dan pelajar menjadi puas. Akan tetapi, sekolah juga harus menyediakan alat-alat belajar dan mengajar yang relevan dengan perkembangan zaman untuk mendukung kemajuan proses pembelajaran dan pengajaran. Gedung sekolah yang bagus diisi dengan sarana dan fasilitas belajar yang baik dan fungsional, tempat bermain pelajar, guru, orang tua, dan masyarakat. Situasi dan kondisi sekolah yang kondusif akan memberikan kontribusi positif bagi mutu proses dan mutu produk (lulusan) sekolah.

3. Pembagian Tanggung Jawab

Pemberdayaan pegawai adalah hal yang sangat penting dalam perbaikan mutu. Oleh karena itu, perlu ada pembagian tanggung jawab sesama pegawai. Adapun guru-guru yang berpendidikan tinggi, berdedikasi, dan bekerja keras, merupakan orang yang seharusnya mengetahui bagaimana mereka bekerja. Para guru dan pegawai dapat diberdayakan sepenuhnya dengan memberikan tanggung jawab dan keterampilan dalam rangka pencapaian kinerja sekolah. Hal itu dapat dilakukan dengan perbaikan manajemen sekolah, terutama untuk menunjang pembaruan proses pengajaran yang lebih mengedepankan tanggung jawab terhadap proses pendidikan yang akan dicapai dalam target untuk mencapai keprofesionalan para guru dengan menyesuaikan kepada keahliannya masing-masing.

4. Pengurangan Sisa Pekerjaan

Dunia pendidikan juga telah mengenal apa yang disebut dengan pengurangan sisa pekerjaan dan pengerjaan ulang serta penambahan jenis-jenis pekerjaan baru. Secara tradisional, pengawasan mutu ditempatkan pada akhir proses produksi sebagai garis pengawasan terhadap kerusakan. Hal ini berarti menjadi tanggung jawab pribadi. Pengawasan seperti itu sangat mahal untuk membuat produk atau output agar jangan sampai kurang sempurna. Pembuatan produk atau output yang baik penting diperhatikan, karena keharusan untuk menghindari pengerjaan ulang atau adanya sisa pekerjaan.

Dalam kegiatan pendidikan, seringkali pengelolaan sekolah bersifat kekeluargaan. Anak-anak yang tinggal kelas dipaksa untuk naik kelas sehingga terhindar ari mengulang kelas. Padahal, pelajar-pelajar yang gagal untuk menguasai materi pengajaran harus mengulang pelajaran tersebut. Sedangkan biaya pengulangan pelajaran adalah besar sekali, dan tenaga serta waktu dihabiskan untuk hal tersebut. Karena itu, pelajar, guru-guru dan orang tua menjadi kecewa dengan kegagalan tersebut. Kondisi ini membuat pelajar seringkali meninggalkan sekolah dari pada mengikuti kembali proses belajar mengajar. Dalam pendidikan disebut juga anak putus sekolah atau drop out. Oleh karena itu, proses yang baik dalam pembelajaran, pekerjaan yang baik dan kejelasan tugas dan tanggung jawab, dan para guru atau 
pegawai yang bermutu, harus diintegrasikan guna mengikis tinggal kelas, mengulang kelas dan kegagalan belajar.

Keempat variabel penting dari konsep pokok manajemen mutu terpadu dalam pendidikan sebagai suatu filsafat perbaikan terus menerus terhadap mutu pendidikan dilengkapi oleh data yang lengkap. Dengan kata lain bahwa manajemen mutu terpadu merupakan manajemen waktu untuk merancang solusi dalam pencapaian tujuan, dan pengambilan keputusan dalam pendidikan untuk menambah nilai pembelajaran dan peningkatan pengajaran. Hal ini dikarenakan bahwa setiap langkah perbaikan mutu menghabiskan waktu dan uang agar pengerjaan ulang tidak menambah frustasi bagi orang tua, pelajar, guru-guru, dewan sekolah, industri dan masyarakat luas.

\section{KESIMPULAN DAN SARAN}

Setelah pemaparan dan analisa data dilakukan, selanjutnya dapat ditarik beberapa kesimpulan, yaitu:

Pertama, proses pengajaran yang dilakukan oleh guru dalam menunjang keberhasilan pengelolaan Madrasah Aliyah Pancasila di Bengkulu belum terlaksana dengan baik. karena guru-guru masih terlambat masuk ruangan untuk menyampaikan materi, metode yang digunakan tidak menarik/tidak cocok dengan materi yang disampaikan, dan guru juga kurang menguasai materi serta adanya peran ganda guru dalam menyampaikan materi mata pelajaran.

Kedua, terjadinya penurunan mutu atau output Madrasah Aliyah Pancasila di Bengkulu disebabkan guru yang tidak menjalankan profesinya sebagai tanggung jawab keahlian, hal ini terlihat saat penggunaan waktu yang tidak efisien, saat menyampaikan materi tidak berdasarkan tujuan pembelajaran khusus (TPK), dan guru tidak menyiapkan perangkat pembelajaran: Analisis Materi Pembelajaran (AMP), Rencana Pembelajaran (RPP), dan Satuan Pengajaran (SP).

Ketiga, faktor-faktor yang menjadi kendala dalam pengajaran di Madrasah Aliyah Pancasila di Bengkulu adalah faktor input siswa/i, pengajar yang tidak tahu tanggung jawab, komunikasi yang tidak berjalan. Sarana dan prasarana yang tidak mendukung.

\section{DAFTAR PUSTAKA}

Arikunto, S. (1988). Pengelolaan Kelas dan Siswa Sebuah Pendekatan Evaluatif. Jakarta: Rajawali Press. 
Hamalik, 0. (1991). Pendekatan Baru Strategi Belajar Mengajar berdasarkan CBSA. Bandung: Sinar Baru.

Hasbullah. (1996). Pembaharuan dalam Islam: Lintas Sejarah Perubahan dan Perkembangan. Jakarta: LSIK.

Ishak, B. (1998). Pengembangan Kurikulum Teori dan Tehnik. Ujung Pandang: Berkah Utama.

Moleong, L J. (1990). Metodologi Penbelitian Qkualitative, Bandung. Remaja: Rosdakarya.

Nasution, S. (1992). Metode Peneltian Naturalistic Kualitatif. Bandung: Tarsito.

(1995). Kurikulum dan Pengajaran. Jakarta, Bumi Aksara.

Poerwadarminta, W.J.S. (1999). Kamus Umum Bahasa Indonesia. Jakarta: Balai Pustaka.

Rifa'i, M. (2003). Ilmu Fiqh Islam Lengkap. Semarang: Toha Putra.

Sardiman, A.M. (1990). Interaksi dan Motivasi Belajar dan Mengajar. Jakarta: Raja Grafindo Persada.

Soewarso, H. (1996). Total Quality Management. Yogyakarta: Andi.

Silverius, S. (1991). Evaluasi Hasil Belajar dan Umpan Balik. Jakarta: Gramedia.

Syafarudin. (2002). Manajemen Mutu Terpadu dalam Pendidikan. Konsep Strategi dan Aplikasi. Jakarta: Gramedia.

Wahjoetomo. (1997). Perguruan Tinggi Pesantren: Pendidikan Alternatif Masa Depan. Jakarta: Gema Insani Press.

Ziemek, M. (1986). Pesantren dalam Perubahan Sosial. Jakarta: Temprit. 